\title{
Biofumigation: A control method for the soil-borne diseases
}

\author{
J. N. SRIVASTAVA* AND ABHIJEET GHATAK
}

Department of Plant Pathology, Bihar Agricultural University, Sabour, BHAGALPUR (BIHAR) INDIA

\section{ARITCLE INFO}

Received : 08.05.2017

Accepted : 28.09.2017

*Corresponding author:
How to view point the article : Srivastava, J.N. and Ghatak, Abhijeet (2017). Biofumigation: A control method for the soil-borne diseases. Internat. J. Plant Protec., 10(2) : 453-460, DOI : 10.15740/HAS/IJPP/10.2/453-460.

KEY WORDS : Biofumigation, Soil-borne diseases

\section{What is biofumigation?}

The term 'biofumigation' was originally coined by J.A. Kirkegaard to describe the process of growing, macerating / incorporating certain Brassica or related species into the soil, leading to the release of isothiocyanate compounds (ITCs) through the hydrolysis of glucosinolate (GSL) compounds contained in the plant tissues (Kirkegaard et al., 1993). This can result in a suppressive effect on a range of soil borne pests and diseases. Biofumigation is the suppression of soil born pests and diseases through the use of plants that produce inhibitory chemicals, also known as secondary metabolites. In most cases these biofumigant plants are chopped and incorporated into the soil so they can release their inhibitory chemicals.

So, "Biofumigation is the use of specialized cover crops, which are grown, mulched and incorporated into the soil prior to cropping. High biomass, especially roots, can provide the traditional benefits of green manure crops and if done right, naturally occurring compounds from the biofumigant crops can suppress soil-borne pests, diseases and weeds."

\section{Common biofumigant crops :}

Plants such as broccoli, cauliflower, mustard, rapeseed, and horseradish contain organic compounds called glucosinolates. When the tissues of these plants are damaged, biologically active chemicals are produced. One of the most important compounds released is isothiocyanate (ITC). The pungency of horseradish and the spicy taste of hot mustard are caused by ITCs released when the tissues are macerated. At low concentrations ITCs are considered beneficial to human health. At high concentrations ITCs are general biocides that behave much like commercial pesticides. In fact, several commercial pesticides including Dazomet, Vapam, and Vorlex depend on an ITC as the active ingredient for pest control.

Some commonly used biofumigant crops include:

- Mustard-oil seed crop

- Sorghum-cereal crop.

\section{Why Brassicas?}

Soil borne organisms are becoming more difficult to control due to pathogen resistance and restricted use 